\title{
A comparative evaluation of relationship between institutional ownership and compositional performance indices in different stages of Iranian corporations' life cycle
}

\author{
Hassan Ghodrati* and Bahareh Nazemi
}

Department of Management and Accounting ,Kashan Branch, Islamic Azad University, Kashan, Iran

\section{H R O N I C L E}

Article history:

Received October 28, 2013

Received in revised format

20 November 2013

Accepted 12 January 2014

Available online

January 162014

Keywords:

Institutional ownership

Life cycle

Compositional performance \begin{abstract}
A B S T R A C T
This article evaluates the relationship between institutional ownership and compositional performance indices in company life cycle among corporations accepted in Tehran Stock Exchange comparatively. In representation relations owner's goal in maximum wealth; therefore, the goal controls the representative work and evaluates his performance. The statistical society in this research consists of corporations accepted in Tehran Stock Exchange over the period 2006-2010. A cross-sectional regression of corporations is obtained and along with different stages of life cycle, their variance is analyzed. The results of this research indicate that:

1. In corporations' growth stage, institutional ownership causes increasing assimilation performance and decreasing economic and financial performance.

2. In maturity stage, institutional ownership causes increasing assimilation performance but it has no effect on financial performance and it has a twofold effect on economic performance.

3. In decline stage, institutional ownership has a twofold effect on assimilation performance and it causes decreasing economic and financial performance.
\end{abstract}

(C) 2014 Growing Science Ltd. All rights reserved.

\section{Introduction}

For many years economists assumed that all groups work on a single joint goal, but during the past thirty years, there were some cases of conflict of interests among various parties. Representational relationship is an agreement given to an employer or owner appoints a representative on his/her behalf and delegates decision-making power to him/her. Corporations' financial scandals in recent years show the relative importance of corporate governance in effective supervision on corporation's performance. Noravesh and Ebrahimi Kordlor (2007) considered the relationship between institutional shareholders and information conjunction. Their research finding revealed that in corporations with more institutional ownership, stock shares price embody more future profits

*Corresponding author.

E-mail addresses: Dr.ghodrati@yahoo.com (H. Ghodrati) 
information compared with corporations with less institutional ownership. They have related this result to institutional shareholders professionally who have relative ability and priority to process information. Dehdar (2006) reviewed the effect of life cycle structure on explanatory power of profit components and cash flow. His findings indicated that in growth and maturity stages, profit-based valuation models and liability items embody more additive explanatory power compared with operative cash flow, investment and funding-based models, but in decline stage its vice versa.

Hoseini (2006) examined the role of institutional shareholders as one of the most important indices of corporate strategic regime on shareholders yield. His research findings suggested that although there was a large-number of institutional shareholders in stock exchange accepted corporations, there was no significant relationship between institutional shareholders and yield, but based on research results carried out in other countries, there is a positive or still negative relationship. Namazi and Kermani (2007) considered 66 corporations from 2003 and suggested that there was a significant and negative relationship between institutional ownership and corporate performance, and there was a significant but positive relationship between corporate ownership and corporation performance. Management ownership affects performance significantly and negatively. Moradzadefar et al. (2010) investigated the relationship between institutional ownership and profit management. Their study results revealed that there was a significant and negative relationship between institutional ownership level and its focus on profit management.

Zanjirdar and Farahani (2009) reviewed the relationship between ownership structure and value of corporations accepted in Tehran Stock Exchange. They reported that there was no relationship between institutional investment and corporation value, but there was a relationship between number of institutional investors and managerial ownership and corporation value. Karimi and Omrani (2010) carried out a study and reported that the level of risk criteria relativity and performance, also additive explanatory power of risk criteria were significantly different from each other in different levels of life cycle on some selected firms on Tehran Stock Exchange.

Osta (2010) studied 95 corporations in Tehran Stock Exchange and reported that there was a significant negative relationship between institutional ownership and managerial ownership with profit management, but there was a significant and positive relationship between corporate ownership and profit management. Black (1998) reviewed the incremental explanatory power of valuation methods based on liability items compared with valuation methods based on cash flows. His findings revealed that the explanatory power of valuation methods based on liability items and cash flow were significantly different from each other in different life cycle stages. Jenkins et al. (2004) examined the effect of corporation life cycle on dividend relevance and suggested that dividend relevance was different, which depends on the fact that corporation is in which life cycle stage.

Chen and Kao (2005) studied 33 Taiwan Stock Exchange active corporations from 1995 to 1999. Focusing on management and ownership structure, they found there was a significant and positive relationship between type of legal ownership and corporations share yield performance.

Navissi and Naiker (2006) used pound theories and considered the relationship between institutional ownership and corporation value in New Zealand. They reported that institutional investors were more motivated to supervise management; therefore, their presence had a positive effect on corporation value, but in higher levels of ownership, institutional investors may encourage board of directors to take unfavorable decisions.

Kallunki and Silvola (2008) studied the level of using activity-based cost finding system in corporation different life cycle stage. In corporations, which were in maturity and different stages, the level of using activity-based cost finding system was higher compared with growth stage. Karami and Omrani (2009) investigated the effect of corporation life cycle and conservatism on corporation value. 


\section{The proposed study}

The proposed study of this paper investigates whether there is a difference between institutional ownership compositional performance indices by concentrating on corporations life cycle stages. There are three sub-hypotheses associated with this study as follows,

1- In growth stage, corporation performance is different based on institutional ownership structure.

2- In maturity stage, corporation performance is different based on institutional ownership structure.

3- In decline stage, corporation performance is different based on institutional ownership structure.

Concerning the goal, the present research is applied; concerning inference, it is deductive, concerning research plan it is classified as ex post facto research, which is based on past information and observed data. Also concerning variables, data and quantitative analytical measures, it is quantitative and non-judgmental because a mathematical algorithm and modeling method is used. The statistical universe consists of corporations accepted in Tehran Stock Exchange but it does not consist of financial intermediaries. No firm was allowed to have more than 3-month-long interruption for trading activities and in the research period, their fiscal year should not have been changed.To state the sample size, the general Cochran formula was used, so considering this formula and using random sampling method, 236 corporations were selected as sample size of this research. The research general relationship is stated as this formula:

$$
Y=F\left(X_{1}, X_{2}, X_{3}, X_{4}\right) \text {, }
$$

$\mathrm{Y}=$ ownership structure, $\mathrm{X}_{1}=$ economic-financial performance and composition, $\mathrm{X}_{2}=$ financial pyramid, $\mathrm{X}_{3}=$ corporation size, $\mathrm{X}_{4}=$ life cycle where,

- Return on assets $=($ ROA $)=$ net profit $/$ total assets

- Stockholders equity return $=(\mathrm{ROE})=$ net profit $/$ book value of stockholders equity

- $\mathrm{MVA}=($ stockholders equity $)-($ stock price) (number of shares issued)

- $\quad$ capital $=(r-c)=$ REVA

- In this formula, M capital represents assets financial and c represents capital cost of corporation which is obtained by weak or harmonic average of capital cost based on market values.

- Current debt without interest - assets book value + common stock and blue chips value $=\mathrm{M}$ capital

- $\mathrm{P} / \mathrm{E}$ ratio common to analyze condition of corporations, industries and market which is obtained by dividing market value of one share by dividend of that share and it represents the amount which shareholders should divided..

- $\mathrm{P} / \mathrm{S}$ ratio, which is obtained by dividing market value of one share by sale of that share.

In our study, the following holds,

$\mathrm{X}_{2}=$ financial pyramid $(\mathrm{LEV})=$ total debt $/$ total asset

$\mathrm{X}_{3}=$ corporation size $=$ corporation sale logarithm

$\mathrm{X}_{4}=$ life cycle which is classified to growth, maturity and decline stages

The propose study uses the following regression analysis 
$Y=\beta_{1} X_{1}+\beta_{2} X_{2}+\beta_{3} X_{3}+\beta_{4} X_{4}+\alpha$ : There is a linear relation between variables. $Y$ is estimated from $n$ variable regression by assessment of $\alpha, \beta_{1}, \beta_{2}, \beta_{3}$, and $\beta_{4}$ parameters.

\section{The results}

We first look at some basic statistics associated with the proposed study of this paper, which are summarized in Table 1 as follows,

\section{Table 1}

The summary of some basic statistics

\begin{tabular}{|c|c|c|c|c|c|c|}
\hline \multirow[t]{2}{*}{ Indices } & \multicolumn{2}{|c|}{ Economic performance } & \multicolumn{2}{|c|}{ Assimilative performance } & \multicolumn{2}{|c|}{ Financial performance } \\
\hline & MVA & REVA & $\mathrm{P} / \mathrm{E}$ & $\mathrm{P} / \mathrm{S}$ & ROE & ROA \\
\hline Number & 500 & 498 & 497 & 499 & 499 & 489 \\
\hline Mean & 452149.36 & 58712590.518 & 10.843 & 1.349 & 0.405 & 0.126 \\
\hline Median & 105298.00 & 1649602.532 & 5.907 & 0.703 & 0.344 & 0.105 \\
\hline Mode & -34502 & -12138446.10 & 0.000 & 0.000 & -1.900 & -0.030 \\
\hline Standard Deviation & 1344738.646 & 3.989 & 61.701 & 1.698 & 0.507 & 0.128 \\
\hline Variance & 1.808 & 1.592 & 3807.077 & 2.885 & 0.257 & 0.016 \\
\hline Bias & 4.699 & 13.495 & 21.962 & 2.872 & 2.383 & 0.101 \\
\hline Standard error of bias & 0.089 & 0.089 & 0.089 & 0.089 & 0.089 & 0.089 \\
\hline Skewedness & 30.009 & 249.364 & 530.452 & 10.563 & 18.836 & 4.224 \\
\hline Standard error of skewness & 0.177 & 0.179 & 0.177 & 0.177 & 0.177 & 0.177 \\
\hline Lowest & -3953158 & -1.38 & -64.194 & .000 & -2.348 & -.717 \\
\hline Highest & 12047781 & 8.26 & 1555.555 & 13.212 & 4.460 & 0.627 \\
\hline
\end{tabular}

Based on the results of Table 1, it seems that REVA variable with 58712590.518 has the highest mean and ROA variable with 0.126 has the lowest mean. The third row represents data median. Median indicates that 50 percent of data are below middle point and 50 percent of data are more than middle point of whole collection. According to these results, REVA variable with 1649602.532 has the highest median and ROA variable with 0.105 has the lowest median. Table 2 shows some other results of our survey.

Table 2

Summary of capital structure descriptive

\begin{tabular}{lccc}
\hline Indices & Financial leverage & Corporation size & Institutional ownership \\
\hline Number & 500 & 489 & 489 \\
Mean & 0.660 & 13.128 & 150929.127 \\
Median & 0.659 & 13.001 & -104152.571 \\
Mode & 0.383 & 11.718 & -5.976 \\
Standard Deviation & 207136851 & 1.317 & 6.447 \\
Variance & 0.043 & 1.736 & 4.157 \\
Bias & 1.495 & 0.899 & 20.034 \\
Standard error of bias coefficient & 0.089 & 0.089 & 0.089 \\
Skewedness & 10.387 & 1.314 & 541.136 \\
Standard error of skewedness & 0.177 & 0.177 & 0.179 \\
Lowest & 0.103 & 10.5565 & -5.976 \\
Highest & 2.356 & 18.195 & 1.618 \\
\hline
\end{tabular}

Table 2 also represents data with the most frequency which considering results of corporation size variable of 11.718 has the highest frequency. Next, we need to make sure whether the data are normally distributed or not and is accomplished by performing Kolmogorov-Smirnov test summarized in Table 3 and Table 4 as follows. 
Table 3

The summary of Kolmogorov-Smirnov test

\begin{tabular}{|c|c|c|c|c|c|c|}
\hline \multirow{2}{*}{ Indices } & \multicolumn{2}{|c|}{ Economic performance } & \multicolumn{2}{|c|}{ Assimilative performance } & \multicolumn{2}{|c|}{ Financial performance } \\
\hline & MVA & REVA & $\mathrm{P} / \mathrm{E}$ & $\mathrm{P} / \mathrm{S}$ & ROE & ROA \\
\hline Number & 500 & 498 & 500 & 500 & 498 & 498 \\
\hline Mean & 452149.36 & 58712590.518 & 10.843 & 1.349 & 0.405 & 0.126 \\
\hline Standard Deviation & 1344738.646 & 3.989 & 61.701 & 1.698 & 0.507 & 0.128 \\
\hline $\begin{array}{l}\text { The most standard } \\
\text { deviation }\end{array}$ & 0.281 & 0.373 & 0.387 & 0.218 & 0.172 & 0.095 \\
\hline $\begin{array}{l}\text { The most positive } \\
\text { deviation }\end{array}$ & 0.281 & 0.373 & 0.382 & 0.216 & 0.171 & 0.086 \\
\hline $\begin{array}{l}\text { The most negative } \\
\text { deviation }\end{array}$ & -0.276 & -0.351 & -0.387 & -0.218 & -0.172 & -0.095 \\
\hline Kolmogorov-Smirnov & 7.748 & 10.208 & 10.656 & 5.997 & 4.727 & 2.623 \\
\hline Significance level & 0.063 & 0.054 & 0.071 & 0.057 & 0.059 & 0.068 \\
\hline
\end{tabular}

\section{Table 4}

The summary of Kolmogorov-Smirnov test

\begin{tabular}{lccc}
\hline Indices & Financial leverage Ln & Corporation size & Institutional ownership Ln \\
\hline Number & 500 & 500 & 500 \\
Mean & 1.566 & 0.335 & 1.316 \\
Standard Deviation & 0.439 & 0.141 & 0.502 \\
The most standard deviation & 0.078 & 0.069 & 0.075 \\
The most positive deviation & 0.078 & 0.069 & 0.075 \\
The most negative deviation & -0.052 & -0.031 & -0.051 \\
Kolmogorov-Smirnov & 1.345 & 1.198 & 1.295 \\
Significance level & 0.054 & 0.113 & 0.070 \\
\hline
\end{tabular}

As shown in Tables 3 and Table 4, the significance level for variables is more than 0.05 . Therefore, data follow normal distribution for variables and to test them, parameter methods can be applied and the results are summarized in Table 5.

1.The Relationship between Institutional Ownership and Return on Asset in Growth Stage: The negative coefficient of institutional ownership variable with a significance level less than 5\% indicates the inverse (negative) relationship of financial performance index in growth stage. It is not possible to delete this variable from regression equation. The second variable, i.e. corporation size, has a direct relationship with asset turnover in growth stage, which is less than $5 \%$. In third stage, debt variable significance level is more than 5\%, so there is no relationship between turnover and this variable and it is erased from equation.

$R O A=0.688-0.001 I N O W N+0.024$ SIZE $+\epsilon_{i}$

2.The Relationship between Institutional Ownership and Return on Asset in Maturity Stage: Institutional variable, debt and corporation size are more $5 \%$, so they are not effective in regression equation and they are erased.

$R O A=0.39+\epsilon i$

3.The Relationship between Institutional Ownership and Return on Asset in Decline Stage: The negative coefficient of institutional ownership with a significance level less than $5 \%$ represents a negative and inverse relationship between ownership and turnover in decline stage. Debt variable is more than $5 \%$, so there is no relationship between debt variable and turnover, so this variable is erased too. Size variable with a significance level less than 5\% has a direct and positive relationship with asset turnover, so it is not possible to erase it from equation.

$R O A=0.022-0.002 I N O W N+0.073$ SIZE $+\epsilon i$ 
Table 5

The summary of regression analysis

\begin{tabular}{|c|c|c|c|c|c|c|c|}
\hline Hypothesis & $\begin{array}{l}\text { Determination } \\
\text { coefficient }\end{array}$ & $\begin{array}{c}\text { Adjusted } \\
\text { determination } \\
\text { coefficient }\end{array}$ & $\begin{array}{l}\text { Durbin } \\
\text { Watson }\end{array}$ & $\mathrm{t}$ & $\mathrm{F}$ & Sig. & result \\
\hline $\begin{array}{l}\text { The relationship between institutional } \\
\text { ownership and ROA in growth stage }\end{array}$ & 0.157 & 0.396 & 1.729 & -3.442 & 6.286 & 0.001 & $\mathrm{H}_{1}$ \\
\hline $\begin{array}{l}\text { The relationship between institutional } \\
\text { ownership and ROA in maturity stage }\end{array}$ & 0.067 & 0.259 & 2.037 & 1.031 & 2.069 & 0.305 & $\mathrm{H}_{0}$ \\
\hline $\begin{array}{l}\text { The relationship between institutional } \\
\text { ownership and ROA in decline stage }\end{array}$ & 0.109 & 0.330 & 1.938 & -2.092 & 4.503 & 0.038 & $\mathrm{H}_{1}$ \\
\hline $\begin{array}{l}\text { The relationship between institutional } \\
\text { ownership and stockholders equity return in } \\
\text { growth stage }\end{array}$ & 0.141 & 0.376 & 1.899 & -3.031 & 5.562 & 0.003 & $\mathrm{H}_{1}$ \\
\hline $\begin{array}{l}\text { The relationship between institutional } \\
\text { ownership and stockholders equity return in } \\
\text { maturity stage }\end{array}$ & 0.071 & 0.266 & 1.871 & 1.222 & 2.183 & 0.224 & $\mathrm{H}_{0}$ \\
\hline $\begin{array}{l}\text { The relationship between institutional } \\
\text { ownership and stockholders equity return in } \\
\text { decline stage }\end{array}$ & 0.110 & 0.331 & 2.325 & -2.114 & 4.528 & 0.036 & $\mathrm{H}_{1}$ \\
\hline $\begin{array}{l}\text { The relationship between institutional } \\
\text { ownership and REVA in growth stage }\end{array}$ & 0.087 & 0.295 & 1.793 & -3.594 & 9.687 & 0.000 & $\mathrm{H}_{1}$ \\
\hline $\begin{array}{l}\text { The relationship between institutional } \\
\text { ownership and REVA in maturity stage }\end{array}$ & 0.089 & 0.299 & 1.988 & -3.754 & 9.998 & 0.000 & $\mathrm{H}_{1}$ \\
\hline $\begin{array}{l}\text { The relationship between institutional } \\
\text { ownership and REVA in decline stage }\end{array}$ & 0.405 & 0.397 & 1.672 & 1.814 & 50.245 & 0.071 & $\mathrm{H}_{0}$ \\
\hline $\begin{array}{l}\text { The relationship between institutional } \\
\text { ownership and MVA in growth stage }\end{array}$ & 0.272 & 0.262 & 1.994 & -0.875 & 27.526 & 0.382 & $\mathrm{H}_{0}$ \\
\hline $\begin{array}{l}\text { The relationship between institutional } \\
\text { ownership and MVA in maturity stage }\end{array}$ & 0.239 & 0.229 & 2.058 & -0.767 & 23.222 & 0.444 & $\mathrm{H}_{0}$ \\
\hline $\begin{array}{l}\text { The relationship between institutional } \\
\text { ownership and MVA in decline stage }\end{array}$ & 0.396 & 0.388 & 1.588 & 10.154 & 48.395 & 0.000 & $\mathrm{H}_{1}$ \\
\hline $\begin{array}{l}\text { The relationship between institutional } \\
\text { ownership and } \mathrm{P} / \mathrm{E} \text { in growth stage }\end{array}$ & 0.332 & 0.323 & 1.582 & 8.067 & 36.727 & 0.000 & $\mathrm{H}_{1}$ \\
\hline $\begin{array}{l}\text { The relationship between institutional } \\
\text { ownership and } \mathrm{P} / \mathrm{E} \text { in maturity stage }\end{array}$ & 0.337 & 0.328 & 1.641 & -4.531 & 37.459 & 0.000 & $\mathrm{H}_{1}$ \\
\hline $\begin{array}{l}\text { The relationship between institutional } \\
\text { ownership and } \mathrm{P} / \mathrm{E} \text { in decline stage }\end{array}$ & 0.186 & 0.175 & 1.563 & -0.406 & 16.810 & 0.685 & $\mathrm{H}_{0}$ \\
\hline $\begin{array}{l}\text { The relationship between institutional } \\
\text { ownership and } \mathrm{P} / \mathrm{S} \text { in growth stage }\end{array}$ & 0.264 & 0.251 & 1.536 & -0.159 & 21.065 & 0.874 & $\mathrm{H}_{0}$ \\
\hline $\begin{array}{l}\text { The relationship between institutional } \\
\text { ownership and } \mathrm{P} / \mathrm{S} \text { in maturity stage }\end{array}$ & 0.267 & 0.257 & 1.975 & -0.785 & 26.894 & 0.433 & $\mathrm{H}_{0}$ \\
\hline $\begin{array}{l}\text { The relationship between institutional } \\
\text { ownership and } \mathrm{P} / \mathrm{S} \text { in decline stage }\end{array}$ & 0.347 & 0.338 & 1.579 & 8.538 & 39.123 & 0.000 & $\mathrm{H}_{1}$ \\
\hline
\end{tabular}

4.The Relationship between Institutional Ownership and Stockholders Equity in Growth Stage: The negative coefficient of institutional ownership with a significance level less than $5 \%$ represents the negative relationship between institutional ownership and stockholders equity return. The significance level for debt variable is more than $5 \%$, so there is no relationship between stockholders equity and debt variable because of which it is erased from equation. Size variable significance level is less than $5 \%$, which represents its positive relationship with stockholders equity return in growth stage.

$$
R O E=0.749-0.193 I N O W N+0.019 S I Z E+\epsilon i
$$

5.The Relationship between Institutional Ownership and Stockholders Equity in Maturity Stage: The significance level of institutional ownership, debt and size is more $5 \%$, so there is no relationship between mentioned variables and stockholders equity return.

$R O E=0.335+\epsilon i$

6.The Relationship between Institutional Ownership and Stockholders Equity in Decline Stage: The negative coefficient of institutional ownership with a significance level less than $5 \%$ represents the negative and inverse relationship between institutional ownership and stockholders equity return. The significance level of debt variable is more than $5 \%$, so there is no relationship between stockholders 
equity and debt variable, because of which it is erased from regression equity. Size variable has a significance level less than 5\%, which shows the positive relationship with stockholders equity.

$R O E=0.079-0.257 I N O W N+0.068$ SIZE $+C i$

7.The Relationship between Institutional Ownership and REVA in Growth Stage: The negative coefficient of institutional ownership with a significance level less than $5 \%$ represents the negative and inverse relationship between institutional ownership and REVA. Corporation debt variable is more than 5\%, so there is no relationship between debt variable and REVA and it is erased from equation. Corporation size variable with a significance level less than $5 \%$ indicates a positive relationship with REVA.

$$
R E V A=0.713-0.142 I N O W N+0.019 S I Z E+C i
$$

8.The Relationship between Institutional Ownership and REVA in Maturity Stage: The negative coefficient of institutional ownership with a significance level less than $5 \%$ represents a negative and inverse relationship between institutional ownership and REVA. Debt variable has a significance level more than 5\%, which represents lack of relationship between REVA and debt variable, so this variable is erased from equation. Corporation size variable has a significance level less than 5\%, so it has a positive relationship with REVA.

$R E V A=0.677+0.001 I N O W N+0.022 \operatorname{SIZE}+\epsilon i$

9.The Relationship between Institutional Ownership and REVA in Decline Stage: Institutional ownership variable coefficient with a significance level more than $5 \%$ represents that there is no relationship between institutional ownership and REVA. Debt variable has a significance level less than 5\%, so there is a relationship between REVA and debt variable, and it is not erased from equation. Considering size significant level, it is not possible to erase it from regression equation, so corporation size variable with a significance level less than 5\%represents its direct and positive relationship with REVA.

$R E V A=1.759-0.487 L E V+0.10 S I Z E+C i$

10.The Relationship between Institutional Ownership and MVA in Growth Stage: Institutional ownership variable coefficient with a significance level more than 5\% indicates lack of relationship between institutional ownership and MVA. Debt variable has a significance level less than 5\%, which proves its relationship with MVA, so it is not erased. Considering size variable significant coefficient, it is level less than 5\%represents its positive relationship with MVA.

$M V A=-3.88-0.872 L E V+0.484$ SIZE $+\epsilon i$

11.The Relationship between Institutional Ownership and MVA in Maturity Stage: Institutional ownership variable coefficient has a significance level more than 5\% represents its lack of relationship with MVA. Debt variable has a significance level is less than $5 \%$ which shows its relationship and it is not erased. Considering size variable significance level it is not possible to remove it from regression equation and because its significance level is less than $5 \%$, there is a positive relationship between this and MVA.

$M V A=-0.469-0.208 L E V+0.109$ SIZE $+C i$

12.The Relationship between Institutional Ownership and MVA in Decline Stage: Institutional ownership variable coefficient has a significance level less than $5 \%$ which shows its positive relationship with MVA. Debt variable significance level is less than 5\%, so it is erased. Considering 
size variable significance level, it is not possible to remove it from regression equation and because its significance level which is less than $5 \%$, it has a positive relationship with MVA.

$M V A=-1.153+1.5108 I N O W N+0.082$ SIZE $+\epsilon i$

13.The Relationship between Institutional Ownership and P/E in Growth Stage: Institutional ownership variable coefficient has a significance level less than $5 \%$ which represents its positive relationship with $\mathrm{P} / \mathrm{E}$. Debt variable significance level is less than $5 \%$, so it has a negative relationship with $\mathrm{P} / \mathrm{E}$ and it is not removed from regression equation. Considering size variable significance level, it is not possible to delete it from regression equation and because of its significance level, which is less than $5 \%$, it has a positive relationship with $\mathrm{P} / \mathrm{E}$.

$P / E=3.038+0.323 I N O W N-0.511 L E V+0.244$ SIZE $+C i$

14.The Relationship between Institutional Ownership and $P / E$ in Maturity Stage: Institutional ownership variable coefficient has a significance level less than $5 \%$ which represents its positive relationship with $\mathrm{P} / \mathrm{E}$. Debt variable significance level is less than $5 \%$, so it has a negative relationship with $\mathrm{P} / \mathrm{E}$ and it is not removed from regression equation. Considering size variable significance level, it is not possible to delete it from regression equation and because of its significance level which is less than $5 \%$, it has a positive relationship with $\mathrm{P} / \mathrm{E}$.

$P / E=2.367+1.259 I N O W N-0.532 L E V+0.244$ SIZE $+C i$

15.The Relationship between Institutional Ownership and $\mathrm{P} / \mathrm{E}$ in Decline Stage: Institutional ownership variable coefficient has a significance level more than $5 \%$ which represents its positive relationship with $\mathrm{P} / \mathrm{E}$. Debt variable significance level is less than $5 \%$, therefore it has a negative relationship with $\mathrm{P} / \mathrm{E}$ and it is not removed from regression equation. Considering size variable significant coefficient, it is removed from equation. Corporation size variable has a significance level less than 5\%, which represented its positive relationship with $\mathrm{P} / \mathrm{E}$.

$P / E=1.7930-0.044$ INOWN $-0.793 L E V+0.089$ SIZE $+\epsilon i$

16.The Relationship between Institutional Ownership and P/S in Growth Stage: Institutional ownership variable coefficient has a significance level more than $5 \%$ which represents its lack of relationship with $\mathrm{P} / \mathrm{S}$. Debt variable significance level is less than $5 \%$, so it is not removed from regression equation. Considering size variable significant coefficient, it is not possible to delete it from regression equation. Corporation size variable has a significance level more than $5 \%$, which represents its positive and significant relationship with $\mathrm{P} / \mathrm{S}$.

$P / S=2.693-0.570 L E V+0.190 S I Z E+C i$

17.The Relationship between Institutional Ownership and P/S in Maturity Stage: Institutional ownership variable coefficient has a significance level more than 5\% which represents its lack of relationship with $\mathrm{P} / \mathrm{S}$. Debt variable significance level is less than $5 \%$, so it is not removed from regression equation. Considering size variable significant coefficient, it is not possible to delete it from regression equation. Corporation size variable has a significance level more than $5 \%$, which represents its positive and significant relationship with $\mathrm{P} / \mathrm{S}$.

$P / S=-2.622-0.869 L E V+0.398 S I Z E+C i$

18.The Relationship between Institutional Ownership and P/S in Decline Stage: Institutional ownership variable coefficient has a significance level less than $5 \%$ which represents positive 
relationship between institutional ownership and $\mathrm{P} / \mathrm{S}$. Debt variable significance level is less than $5 \%$, so it is not removed from regression equation. Considering size variable significant coefficient, it is not possible to remove it from regression equation. Corporation size variable significance level is more than 5\% which represents its positive and significant relationship with $\mathrm{P} / \mathrm{S}$.

$$
P / S=2.790+0.385 I N O W N-0.458 L E V+0.241 S I Z E+C i
$$

\section{Discussion and Conclusion}

This research has evaluated the relationship between institutional ownership and compositional performance indices in different life cycle stages of corporations accepted in Tehran Stock Exchange comparatively. The statistical universe of this research consists of corporations accepted in Tehran Stock Exchange over the period 2006-2010, and statistical sample was selected from them using Cochran formula. To evaluate corporation performance, their financial, economic and compositional performances were considered and each one was classified into two indices. To classify corporations to triple stages of life cycle, Anthony and Ramesh classification method is applied. Then a crosssectional regression of corporations has been obtained and along with different stages of life cycle their variance has been analyzed. The results of this research have indicated that in corporations growth stage, institutional ownership cause increasing assimilation performance and decreasing economic and financial performance; in maturity stage, institutional ownership causes increasing assimilation performance, but it has no effect on financial performance and it has a twofold effect on assimilation performance and it causes decreasing economic and financial performance.

\section{References}

Black, E. L. (1998). Life-cycle impacts on the incremental value-relevance of earnings and cash flow measures. Journal of Financial Statement Analysis, 4, 40-57.

Chen, A., \& Kao, L. (2005). The conflict between agency theory and corporate control on managerial ownership: The evidence from Taiwan IPO performance. International Journal of Business, 10(1), 39-61.

Dehdar, F.(2006), Designing and presenting premium valuation methods based on accounting earnings and cash flows in corporation life cycle process. Accounting Ph.D thesis, Tarbiat Madarres University [In Persian].

Hoseini, S.(2006). Studying institutional stockholders effect as a corporate governance criterion on stockholders return in corporations accepted in Tehran Stock Exchange. Master's Thesis, University of Tehran [In Persian].

Jenkins, D. S., Kane, G. D., \& Velury, U. (2004). The impact of the corporate life-cycle on the valuerelevance of disaggregated earnings components. Review of Accounting and Finance, 3(4), 5-20.

Kallunki, J. P., \& Silvola, H. (2008). The effect of organizational life cycle stage on the use of activity-based costing. Management Accounting Research, 19(1), 62-79.

Karami, G., \& Omrani, H. (2009). The effect of corporation life cycle and conservatism on corporation value. Accounting and Auditing, 2 [In Persian].

Moradzadefar, M., Nazemi, M., Gholami, M., \& Farzani, R. (2006). Studying the relationship between institutional ownership and profit management in corporations accepted in Tehran Stock Exchange. Accounting Surveys Journal, Tehran University Auditory, 55-85.

Navissi, F., \& Naiker, V. (2006). Institutional ownership and corporate value. Managerial Finance, 32(3), 247-256.

Namazi, M., \& kermani, A. (2007). The effect of ownership structure on performance of corporations accepted in Tehran Stock Exchange. Accounting and Auditing Survey, 53 [In Persian].

Noravesh, I., \& Ebrahimi Kordlor, A. (2007). Studying and stating the relationship between shareholders composition and information conjunction and performance accounting indices advantages. Accounting and Auditing Surveys, 42 [In Persian]. 
Osta, S. (2010). Studying the relationship between ownership structure and profit management. Financial Accounting Researches Journal, 2 [In Persian].

Zanjirdar, M., \& Farahani, Z. (2009). Comparing performance measurement system and balanced bonus card analysis as a new performance measurement system. Arak Azad Islamic University [In Persian]. 